\title{
Quality of commercial soybean grain and post-harvest economic losses in farming in West Pará, Brazil
}

\author{
Juliana Amaral Vinhote ${ }^{1}$, Gabriel Coradini ${ }^{1}$, Éder Bruno Rebelo da Silva ${ }^{2}$, Welligton Conceição da Silva ${ }^{2}$, Antônio \\ Vinicius Correa Barbosa ${ }^{2}$, Maria Roseane Pereira dos Santos ${ }^{3}$, Gilbson Santos Soares ${ }^{1,4}$ \\ ${ }^{1}$ Universidade Luterana do Brasil - ULBRA. ${ }^{2}$ Universidade Federal Rural da Amazônia - UFRA, PA. ${ }^{3}$ Universidade Federal \\ do Oeste do Pará - UFOPA, PA. ${ }^{4}$ Instituto Federal do Pará - IFPA, PA. E-mail: julianavinhote@rede.ulbra.br
}

\begin{abstract}
The soybean production chain is one of the main agribusiness products. In this context, the grain market is constantly expanding. Thus, it is important to carry out the characterization of soybeans and define their qualities. The objective of this study was to evaluate the quality of commercial soybean grains in postharvest, as well as the economic losses in a crop in the municipality of Mojuí dos Campos, Pará. Two types of cultivars at 4280 (IPRO) and 8644 (IPRO) were used, harvested on different days and plots. Data collection was carried out by monitoring the post-harvest process. The information regarding the grains was obtained through the classification report provided by the company accredited to classify the grains. The methods used were carried out in accordance with the Technical Regulation of Soybeans of Normative Instruction No. 11, of May 15, 2007, of the Ministry of Agriculture, Pecuária e Abastecimento (MAPA). Data were analyzed by PROC TTEST in SAS version 19.0 at a significance level of $5 \%$. The results showed that, in the period of harvesting of cultivar 8644(IPRO), there was a higher rate of rainfall compared to the days of harvesting of cultivar 4280(IPRO). The total of discounted grains was 15.101 t for the cultivar 4280 (IPRO). The wet grain is the only parameter responsible for the discount in both cultivars. The total of discounted grains referring to cultivar 8644 (IPRO) was 30.218 t. The wet grains for the cultivar had the highest classification rate on the fourth day of harvest, with a total of $23.20 \%$, being related to the decrease in the percentage of broken grains (1.60\%) and a higher index of burnt/damaged grains. It is concluded that the cultivar 4280 (IPRO) presented a lower grain discount compared to the cultivar 8644 (IPRO). Consequently, cultivar 8644 presented greater economic damage to the property.
\end{abstract}

Keywords: quantitative classification of grains; moisture; Glycine max; qualitative classification of grains.

Qualidade de grãos comerciais de soja e perdas ecônomicas na pós-colheita em lavoura no Oeste do Pará, Brasil

\section{RESUMO}

A cadeia produtiva da soja é um dos principais produtos do agronegócio. Nesse contexto, o mercado de grãos está em constante expansão. Assim, faz-se importante realizar a caracterização dos grãos de soja e definir as suas qualidades. $O$ objetivo neste estudo foi avaliar a qualidade de grãos comerciais de soja na pós-colheita, bem como as perdas econômicas em uma lavoura no município de Mojuí dos Campos, Pará. Foram utilizados dois tipos de cultivares a $4280^{(\text {IPRO) }}$ e $8644^{\text {(IPRO) }}$, colhidas em diferentes dias e parcelas. A coleta dos dados foi realizada por meio do acompanhamento do processo de pós-colheita. As informações referentes aos grãos foram obtidas por meio do Laudo de classificação fornecido pela empresa credenciada a classificar os grãos. Os métodos empregados foram realizados conforme o Regulamento Técnico da Soja da Instrução Normativa № 11, de 15 de maio de 2007, do Ministério da Agricultura, Pecuária e Abastecimento (MAPA). Os dados foram analisados pelo PROC TTEST no SAS versão 19.0 a um nível de significância de $5 \%$. Os resultados mostraram que, no período de colheita da cultivar $8644^{(\text {(PRO) }}$, houve um maior índice de precipitação pluvial em comparação com os dias de colheita da cultivar $4280^{\text {(IPRO) }}$. O total de grãos descontados foi de 15,101 t para a cultivar $4280^{(\text {(IRRO) }}$. O grão úmido é o único parâmetro responsável 
pelo desconto em ambas as cultivares. O total de grãos descontados referentes à cultivar $8644^{\text {(IPRO) }}$ foi de 30,218 t. Os grãos úmidos para a cultivar obtiveram maior taxa de classificação no quarto dia da colheita com total de $23,20 \%$, tendo relação com a diminuição da porcentagem dos grãos quebrados $(1,60 \%)$ e um maior índice de grãos ardidos/avariados. Conclui-se que a cultivar $4280^{(\mathrm{IPRO})}$, apresentou menor desconto de grãos em comparação com a cultivar $8644^{(\text {IPRO) }}$. Por consequência a cultivar 8644 apresentou maior dano econômico à propriedade.

Palavras-chave: classificação quantitativa de grãos; umidade; Glycine max; classificação qualitativa de grãos.

\section{Introduction}

Soybean (Glycine max) belongs to the Fabaceae (legume) family, from the Asian continent, in the region of ancient China, its grain has a high protein content and a large amount of essential amino acids for the functioning of the human body (POLLNOW et al., 2020). In Brazil, soybean crops reach 37.03 million planted hectares, representing a production of 126 million tons in the 2019 harvest (CONAB, 2020).

In national and global agribusiness, soy is one of the crops of great economic importance. This fact favors the development and structuring of the international market, the consolidation of the grain as a source of vegetable protein, and the emergence of new technologies that enabled the expansion of exploration in different regions of the world (HIRAKURI; LAZZAROTTO, 2014; BUSS et al., 2019).

Soybeans suffer several interferences in their quality, which can occur in the field, during harvesting and drying, in processing and storage, transport and sowing (FRANÇA NETO et al., 2016). Factors that can intensify due to temperature extremes during maturation, fluctuations in relative air humidity, drought, nutritional and water deficit, occurrence of pests and diseases, in addition to inadequate procedures during harvesting, drying and storage, in addition, the excess of moisture causes deterioration before harvesting, which can result in high rates of mechanical damage (VINHOTE et al., 2021).

The quality of soy beans is the main parameter for their commercialization and processing, because when they occur inappropriately, they affect the price of the product, a fact that shows that Brazilian agriculture still does not fully control losses during the post-harvest, as they suffer interference of external factors, being physical, such as temperature, humidity; chemical, such as oxygen supply, and biological, such as bacteria, fungi, insects and rodents (SAATH et al., 2017).

Soybean classification takes place in accordance with Normative Instruction No. 11, of May 15, 2007, of the Ministry of Agriculture, Pecuária e Abastecimento (BRASIL, 2007a; 2007b), which standardizes defects, rules and limits of soy beans for the commercialization. The main patterned defects are: burnt grains, hot grains, moldy grains, fermented grains, sprouted grains, immature grains, damaged grains, empty grains. Being classified as greenish, the grains or pieces of grain with complete physiological development. Damaged grains represent the sum of burnt, hot, moldy, fermented, germinated, immature, damaged by pests and empty grains, with a tolerance of $8 \%$. Moist grains, those with a variable proportion of water inside, have a tolerance of 14\% (BRASIL, 2007a).

Thus, soybeans for commercialization must present normative standards, seeking quality models for the grains and adequate processes during their processing, which starts at harvest and extends throughout the entire cycle, until its processing, aiming to reduce losses and reduce the injuries on the grain. In this context, this study is justified by the need to identify, according to official standards, the characteristics of soybeans subject to commercialization, observing whether market requirements are met with aptitude and homogeneous quality, spotting the main injuries present in Soy.

In addition, in the post-harvest, the classification of grains is essential, as it will present more consistent responses, which may be physical, physiological or mechanical, encouraging the scientific community to use this tool and aiming to address in a timely manner the origin of the damage caused by the production of soybeans in Brazil (VINHOTE et al., 2021).

The hypothesis of this study was that there are differences in the quality of soybeans 
harvested on different days when comparing two types of cultivars 4280(IPRO) and 8644(IPRO). Based on this information, the aim of this study was to evaluate the quality of commercial soybean grains in post-harvest, as well as the economic losses in a crop in the municipality of Mojuí dos Campos, Pará.

\section{Material and Methods}

The study was carried out in a soybean plantation, located in the municipality of Mojuí

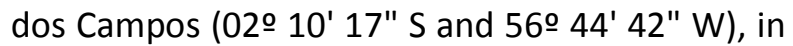

the north of Pará. With a territorial area equivalent to $4,988,236 \mathrm{~km}^{2}$, the soybean crop has a total area of 124.63 ha, (59.46 - 4280) (65.17 - 8644) which was divided into plots according to the corresponding cultivar and collection day, which is shown in Figure 1.

Figure 1. Location map of harvesting areas, Mojuí dos Campos, Pará.

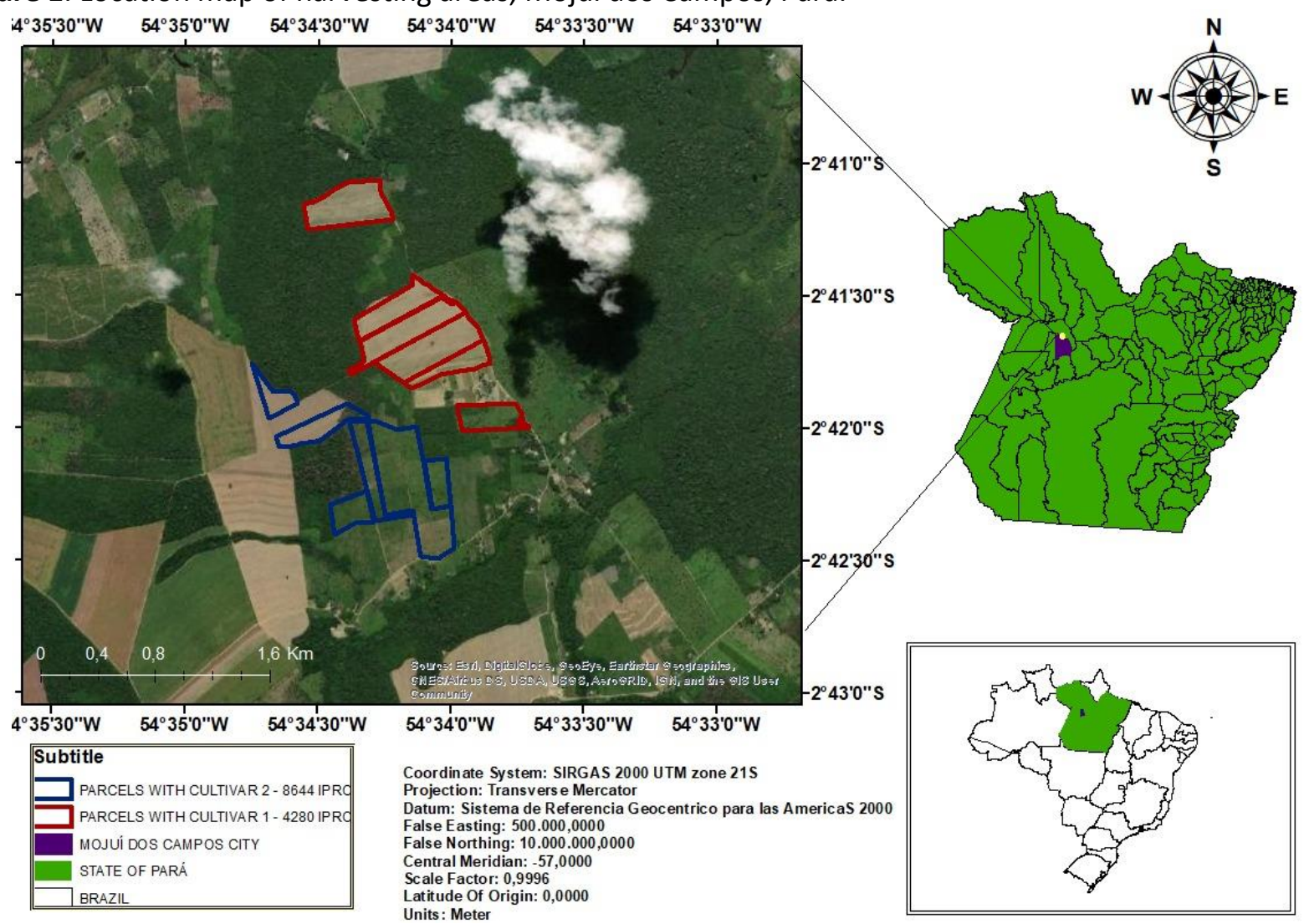

In this study, two types of cultivars were used, the 4280(IPRO) and the 8644(IPRO). The first has greater tolerance to rain at the time of harvest.

Both cultivars were planted and harvested on the same type of soil. The soil texture was characterized by the combination of clay, silt and sand. Among those, clay was the one that presented the greatest quantity. According to the soil analysis report carried out on the property, the soil can be classified as very clayey.

And so, the necessary corrections, fertilization and cultural treatments were made to receive sowing, according to technical recommendations, thus adopting the spacing between rows of $0.45 \mathrm{~m}$, density of 10 plants $/ \mathrm{m}$ 1 for the cultivars.

Data collection was carried out for three days by monitoring the harvest and post-harvest process until the transfer to the accredited company responsible for grain classification.

The harvest of both cultivars took place on different days and plots (Figures 2 and 3), being fully mechanized, and the harvester displacement speed was $6 \mathrm{~km} / \mathrm{h}^{-1}$. 
Figure 2. Cultivar harvest area, photographed by Drone (Brand Xiaomi, model FIMI X8 SE).

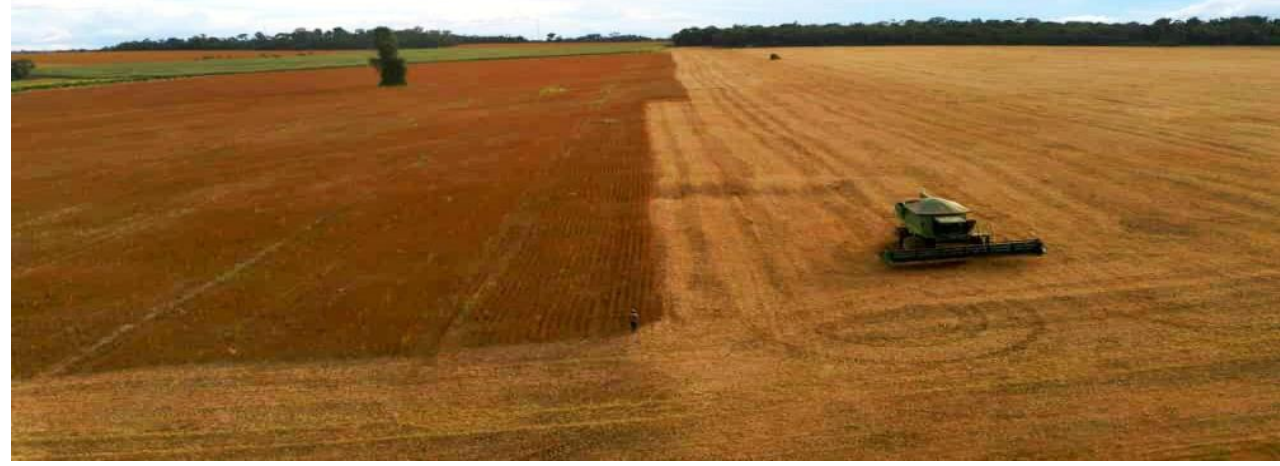

Figura 3. Location map of harvesting areas for cultivar 4280(IPRO) and 8644(IPRO), Mojuí dos Campos, Pará.

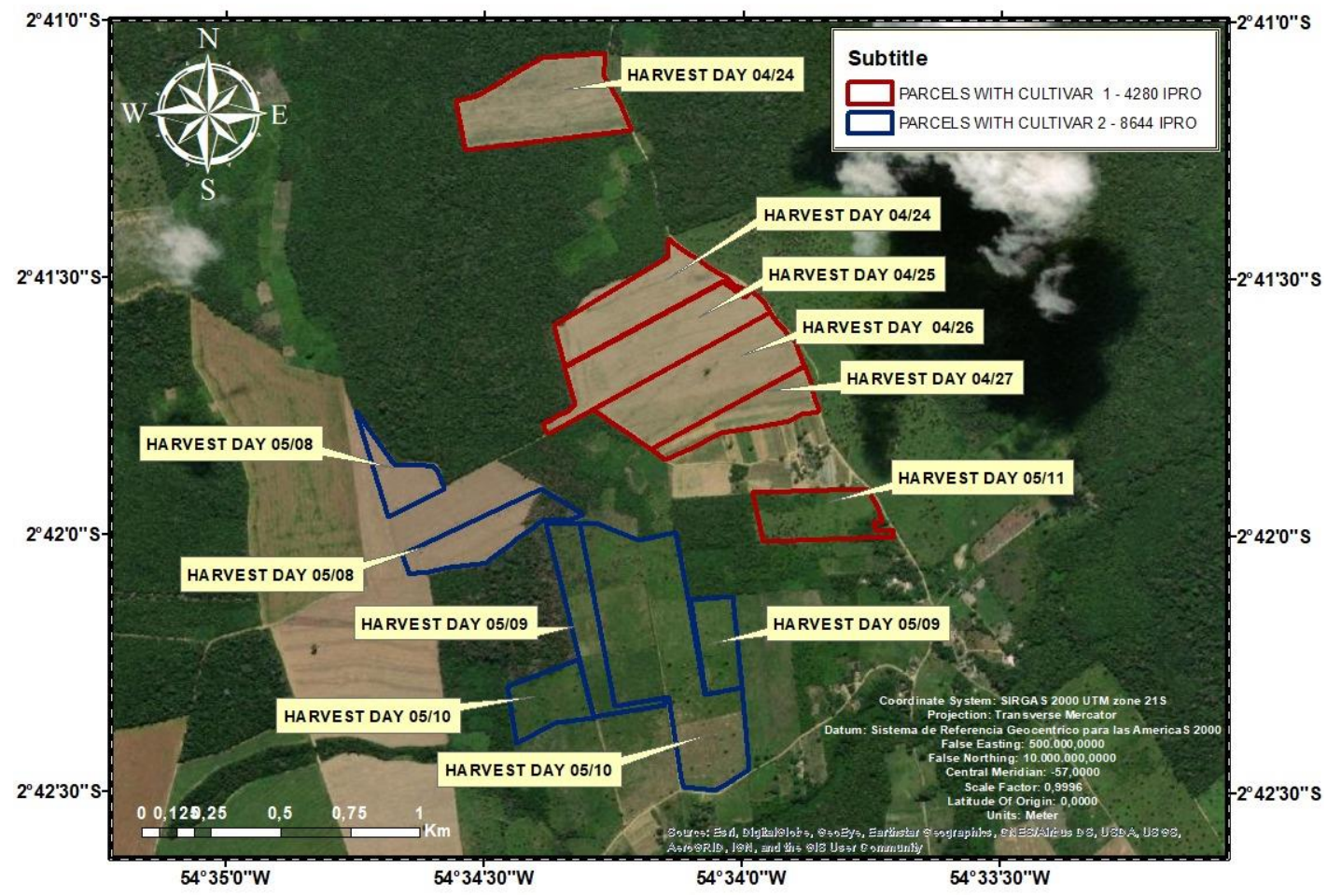

Information regarding rainfall during harvest of soybean cultivars was also collected. For this, a rain gauge was used.

Information related to the grains were obtained through a classification report provided by the company authorized to classify the soy grains destined for commercialization, based on their intrinsic and extrinsic qualities.

The methods used were carried out in accordance with the Technical Regulation of Soybean Normative Instruction No. 11, of May
15, 2007, of the Ministry of Agriculture, Pecuária e Abastecimento (MAPA), referring to sampling and the process of obtaining these, standardized with the values prefixed.

The parameters evaluated are qualitative, which are characterized according to the defects, and quantitative, which are related to the levels of tolerance of the defects found, which are displayed in percentages.

Classification of soy beans was carried out in compliance with the current Normative 
Instruction following the chronological order as shown in the flowchart below:

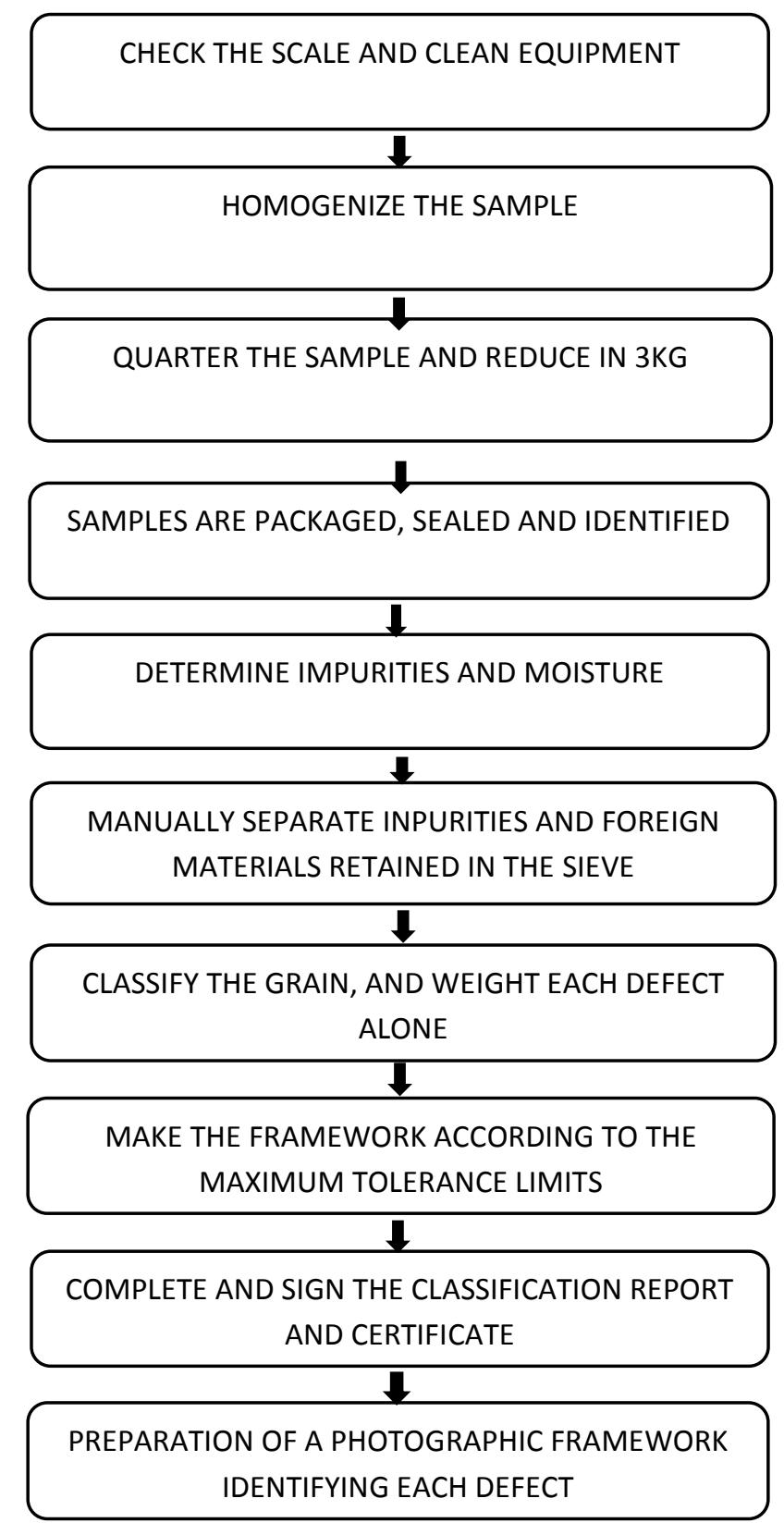

To calculate the percentage of damaged grains, the formula was adopted:

$$
\begin{gathered}
\%=\text { damaged grain weight }(\mathrm{g}) \times 100 \text { sample } \\
\text { weight }
\end{gathered}
$$

The total value of damaged groups represented by burnt $(Q)$, scorched $(A)$, moldy $(M)$, fermented $(F)$, germinated $(G)$, damaged $(D)$, immature (I) and empty (C) will be determined by middle of the formula:

$$
\sum(Q+A+M+F+G+D+I+C)=\text { following formula was used: }
$$

To determine the percentage of foreign matter and impurities - MEI, the formula will be used:

\section{$\%=$ MEIweight $(g) \times 100$ sampleweight}

To estimate the economic loss caused by the discount of wet grains, the total weight of the discounted grains was used, in relation to the value, in reais, practiced during the month of May 2021, equivalent at the time of the research to $\mathrm{R} \$ 160.00 /$ sack.

To calculate the economic loss, the 
19) Discounted total weight / sack weight $(60 \mathrm{~kg})$

29) Sack value vs. total discounted sacks

After collection, data were tabulated and later organized in Microsoft Office Excel $^{\circledast}$ spreadsheets (2016). These were analyzed statistically by PROC TTEST in SAS version 19.0 at a significance level of $5 \%$.

\section{Results and Discussion}

Regarding rainfall, it was found that during the harvest period of cultivar 8644(IPRO), there was a higher rate of rainfall compared to the days of harvest of cultivar 4280 (IPRO), as seen in Figure 4.

Figure 4. Rainfall data in the four days of collection for each cultivar.

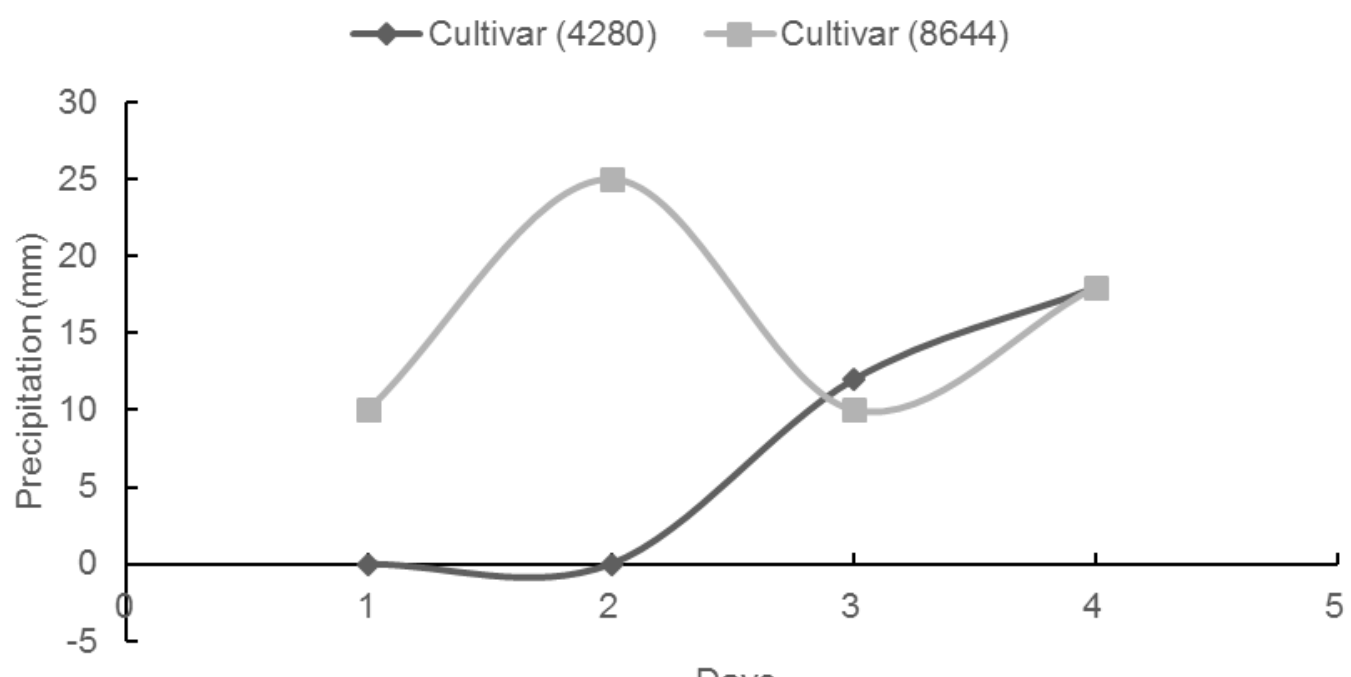

Days

The total of discarded grains was $15.101 \mathrm{t}$, which corresponds to an index of $7.42 \%$ grain discount due to damage to the soybeans for cultivar 4280 (IPRO), with the wet grain being the only parameter responsible for the discount. Table 1 shows the classification of grains.

The total of discarded grains referring to cultivar 8644(IPRO) was 30.218t, which corresponds to an $11.24 \%$ grain discount rate due to general damage to soybean grains.

Table 1 shows the classification of grains. As also observed in the cultivar (4280IPRO), the wet grain was the only parameter responsible for the grain discount.

Table 1. Classification of grains, Mojuí dos Campos, Pará.

\begin{tabular}{|c|c|c|c|c|c|}
\hline \multicolumn{6}{|c|}{ Data in \% (Cultivar 4280 ${ }^{(\text {IPRO) }}$ ) } \\
\hline Day & Moisture & Impurities & Hot/Damaged & Broken & Greenish \\
\hline 1 & 17,16 & 0,30 & 2,46 & 9,16 & 0 \\
\hline 2 & 18,75 & 0,65 & 2,40 & 8,10 & 0 \\
\hline 3 & 19,70 & 0,60 & 2,85 & 4,95 & 0 \\
\hline 4 & 23,20 & 0,30 & 4,70 & 1,60 & 0 \\
\hline \multicolumn{6}{|c|}{ Data in \% (Cultivar $8644^{(\mathrm{IPRO})}$ ) } \\
\hline 1 & 21,55 & 0,75 & 6,30 & 6,00 & 0 \\
\hline 2 & 22,90 & 0,30 & 2,55 & 2,80 & 0 \\
\hline 3 & 18,43 & 0,63 & 3,13 & 4,40 & 0 \\
\hline 4 & 19,15 & 0,70 & 4,10 & 4,35 & 0 \\
\hline
\end{tabular}

Thus, wet grains had a higher classification index on the fourth day of harvest, with a total of $23.20 \%$, related to the decrease in the percentage of broken grains $(1.60 \%)$ and a 
higher index of burnt/damaged grains. In accordance with the data from the present study, Lacerda et al. (2003) evidenced the dependence between grain moisture and rainfall, thus requiring the chemical desiccation process in order to dehydrate the grains, since the high moisture content in the studied plots would not be ideal for the moment of harvest. Therefore, it is noted that the water content is extremely important, as described by Botelho et al., 2016, Santos et al., 2016 e Khan et al., 2017.

When there was a lower moisture rate (17.16\%) there was an increase in the broken grain index $(9.16 \%)$. Corroborating this study, Marcondes et al. (2005) verified the relationship between soybean grain moisture and low rainfall, observing grains with a lower percentage of moisture. It is noteworthy that the presence of broken grains is more evident when the grain has less moisture, making it more easily breakable (CARRARO et al., 1985). Grains harvested with humidity above $18 \%$ may show damage, especially during threshing. On the other hand, grains with a moisture content below the recommended become more sensitive to breakage, thus presenting higher levels of broken grains (FRANÇA NETO et al., 2007).

In cultivar 8644 (IPRO) it was also possible to observe a high moisture content $(22.90 \%)$ on the second day, being related to the decrease in the broken indexes (2.80\%). Corroborating the data described in this study, Borges et al. (2006) described that the delay in harvesting on grain yield caused significant losses, which were mainly influenced by the rainfall and genetic characteristics of the cultivars. Furthermore, late harvesting can lead to the deterioration of the physiological quality of the grains (DINIZ et al., 2013; XAVIER et al., 2015). This fact was evidenced in the harvest period of cultivar 8644 (IPRO), since it was delayed due to mechanical failures of the harvester, followed by high rainfall, thus delaying the ideal time for grain harvest.

The high losses observed during harvesting in this study may have occurred mainly due to the high frequency of rainfall (TSUKAHARA et al., 2016). This fact was evidenced in the harvest of the 8644 (IPRO) culture, in which the rainfall index was more intense (Figure 4). Sales (2017) reinforces that the high frequency of rainfall, associated with fluctuations in relative humidity and temperature fluctuations, lead to losses in the physical, physiological and sanitary quality of the grains. Still in this context, Borém (1999) states that soybean is characterized as an annual crop that presents variability of morphological characteristics, being directly influenced by climatic variables.

The classification showed indexes of burnt/damaged grains and the presence of impurities, all within the accepted range. During classification, burned grains are considered as one of the most important defects, as the fermentation process results in the browning of the grain, reducing its commercial quality (TEIXEIRA, 2001; BRASIL, 2007b). According to Souza (2012), when storing grains with a high percentage of burnt, that is, above acceptable limits, there are not only economic losses, as burnt grains have mycotoxins that in small quantities can affect human and animal health.

In the present study, the presence of impurities was evidenced in the volumes of analyzed samples. According to Lourenço (2019), less than $1 \%$ of impurities is associated with a good adjustment of the machine at the time of harvest, indexes greater than $1 \%$ make it more difficult to process the grains, making it necessary to go through more sieves. Botelho et al. (2019) describe that impurities are classified by the attribute of the physical quality of the grain, which refers to the quality of each batch by the grain and inert material index, number of grains of other species and harmful grains tolerated and prohibited.

It was also evidenced that both cultivars did not show greenish grain rate in the classification. Thus, França Neto et al. (2012) state that greenish beans are soybeans that have not reached their physiological development, which are subject to biotic or abiotic stresses, which, due to the application of products, end up presenting premature death or forced maturation, producing greenish beans with low physiological quality. The presence of greenish grains occurs due to the occurrence of inadequate temperatures, which accelerate the translocation of photoassimilates with lower rates of photosynthesis, which block the degradation of chlorophyll, resulting in greenish and poor quality grains (MARCOS FILHO, 2005).

In addition, greenish beans present high deterioration rates, which can result in reduced germination and vigor of soybean lots (FRANÇA NETO et al., 2016). 
There was the presence of damaged grains, specifically hot ones. In this context, damaged grains represent the sum of the grains that suffered damages during the harvesting process, comprising the hot, moldy, fermented, damaged, immature, hollow, germinated and burnt grains, with a tolerance of $8 \%$ in the commercialization of grains.
In this study, the economic losses identified by the grain discount correspond, in current values, to $\mathrm{R} \$ 120,850.66$. Of these, the greatest economic loss corresponded to cultivar 8444(IPRO) (Table 2).

Table 2. Grains and economic losses in reais, Mojuí dos Campos, Pará, Brazil.

\begin{tabular}{cccc}
\hline Cultivar & Sack weight (kg) & Sack value (R\$) & Economic loss (R\$) \\
\hline $4280^{(\text {IPRO) }}$ & 60 & 160,00 & $40.269,33$ \\
$8644^{(\text {IPRO) }}$ & 60 & 160,00 & $80.581,33$ \\
Total & - & - & $120.850,66$ \\
\hline
\end{tabular}

When performing the statistics of the data regarding the classification of grains for the two cultivars under study, it was observed that there was no significant difference $(p>0.05)$ between the studied variables, that is, this result indicates that both cultivars have similarity in classification of grains, even with the difference existing in the days of harvest regarding rainfall (Table 3).

Table 3. Grain classification statistical data for cultivar 4280(IPRO) and 8644(IPRO).

\begin{tabular}{cc}
\hline Variables & P value \\
\hline Moisture & 0,6380 \\
Impurity & 0,2070 \\
Hot/Damaged & 0,0860 \\
Broken & 0,4236 \\
\hline
\end{tabular}

Note $=p$ value greater than 0.05 has no statistical difference.

\section{Conclusion}

Based on this information, it was possible to identify that cultivar 4280(IPRO) had a lower grain discount compared to cultivar 8644(IPRO). Consequently, cultivar 8644 presented greater economic damage to the property. Regarding impurities, it was noted that the variable moisture exceeded the acceptable limits in both cultivars, it was also found that the days with higher rainfall caused influence on moisture, resulting in a reduction in the percentage of broken grains.

There were no greenish grains, however, the classification showed indexes of hot/damaged grains and the presence of impurities, all within the accepted range, and moisture was the only factor that contributed to the discount of soybeans, causing considerable economic losses for the producer.

As an intervention measure, the use of grain dryers on the property is recommended, in order to prevent the soy beans from retaining high concentrations of water, which, as a consequence, may cause them to be discounted.

\section{References}

BORÉM, A. Escape gênico. Biotecnologia, Ciência e Desenvolvimento (Encarte Especial), p.101107, 1999.

BORGES, I. O.; MACIEL, A. J. S.; MILAN, M. Programa computacional para o dimensionamento de colhedoras considerando a pontualidade na colheita de soja. Engenharia Agrícola, v.26, p.131-141, 2006. https://doi.org/10.1590/S0100$\underline{69162006000100015}$

BRASIL. Ministério da Agricultura, Pecuária e Abastecimento. Instrução normativa n. 11, de 15 de maio de 2007. Estabelece o Regulamento Técnico da Soja, definindo o seu padrão oficial de classificação, com os requisitos de identidade e qualidade intrínseca e extrínseca, a amostragem 
e a marcação ou rotulagem. Diário Oficial da República Federativa do Brasil, Brasília, n.93, p.13-15, 16 maio 2007a. Seção 1.

BRASIL. Ministério da Agricultura, Pecuária e Abastecimento. Instrução normativa n. 37, de 27 de julho de 2007. Altera o inciso IV, do art. $2^{\circ}$, do Capítulo I, do anexo da Instrução Normativa n. 11 , de 15 de maio de 2007, que passa a vigorar com alterações, dando-se nova redação às alíneas " $b$ " e " $g$ " e acrescentando-se a alínea " $h$ ". Diário Oficial da República Federativa do Brasil, Brasília, n. 145, p. 9, 30 jul. 2007b. Seção 1.

BUSS, R. N.; MENDANHA, J. F.; SILVA, D. M.; SIQUEIRA, M. G. Infraestrutura logística de transporte e armazenagem da soja no estado do Maranhão - Brasil. Brazilian Journal of Development, v.5, n.12, p.31564-31580, 2019. https://doi.org/10.34117/bjdv5n12-247

CARRARO, I. M.; BECO, A.; ROCHA, A. Efeito do retardamento da colheita sobre a qualidade de grãos de soja em Palotina, PR. Revista Brasileira de Grãos, v.7, p.123-132, 1995. https://doi.org/10.17801/0101-

3122/rbs.v7n3p123-132

CONAB. Acompanhamento da safra brasileira: grãos - Safra 2019. Brasília, 2020. Disponível em: https://www.conab.gov.br/conteudos.php?a=12 53\&t=.pdf. Acesso em: 27 Jul. 2021.

DINIZ, F. O.; REIS, M. S.; DIAS, L. A. S.; ARAÚJO, E. F.; SEDIYAMA, T.; SEDIYAMA, C. A. Physiological quality of soybean seeds of cultivars submitted to harvesting delay and its association with seedling emergence in the field. Journal of Seed Science, v.35, p.147-152, 2013. https://doi.org/10.1590/S2317-

15372013000200002

FRANÇA NETO, J. B.; KRZYZANOWSKI, F. C.; HENNING, A. A.; PÁDUA, G. P.; LORINI, I.; HENNING, F. A. Tecnologia da produção de grão de soja de alta qualidade. Londrina: Embrapa Soja, 2016. 84 p (Circular técnico. Documento; 380).

FRANÇA NETO, J. B.; KRZYZANOWSKI, F.C.; PÁDUA, P.; COSTA, N.P.; HENNING, A. Tecnologia da produção de grãode soja de alta qualidade Série Grãos. Londrina: Embrapa Soja, 2007. 12p. (Embrapa Soja. Circular técnica, 40).
FRANÇA NETO, J. B.; PÁDUA, G. P.; KRZYZANOWSKI, F. C.; CARVALHO, M. L. M.; HENNING, A. A.; LORINI, I. Grão esverdeada de soja: causas e efeitos sobre o desempenho fisiológico. Londrina: Embrapa, 2012. (Série Grãos; n.91, 16 p.)

HIRAKURI, M. H.; LAZZAROTTO, J. J. O agronegócio da soja nos contextos mundial e brasileiro. Documentos, v. 349, p. 1-70, 2014.

LACERDA, A. L. S.; LAZARINI, E.; SÁ, M. E.; VALÉRIO FILHO, V. V. Aplicação de dessecantes na cultura de soja: teor de umidade nas grãos e biomassa nas plantas. Planta Daninha, v.21, p.427-434, 2003. https://doi.org/10.1590/S0100$\underline{83582003000300011}$

LOURENÇO, W. C. Estudo de caso: Caracterização de cargas de grãos de soja da empresa Chapada Grãos, na safra 2018/2019. 2019. Monografia (Graduação) - Universidade Federal de Santa Catarina, Campus Curitibanos Agronomia, 2019.

MARCONDES, M. C.; MIGLIORANZA, E.; FONSECA, I. C. B. Danos mecânicos e qualidade fisiológica de grãode soja colhida pelo sistema convencional e axial. Revista Brasileira de Grãos, v.27, p.125-129, 2005. https://doi.org/10.1590/S0101$\underline{31222005000200018}$

MARCOS FILHO, J. Fisiologia de grãos de plantas cultivadas. Piracicaba: Fealq, 2005. 495 p.

POLLNOW, H. E.; PIMENTEL, J. R.; POLLNOW, C.; PETER, M.; MEDEIROS, L. B.; PETER, M.; AUMONDE, T. Z.; PEDÓ, T. Manejo da adubação de base em soja no Noroeste do Rio Grande do Sul. Brazilian Journal of Development, v.6, n.6, p.38913-38923, 2020. https://doi.org/10.34117/bjdv6n6-435

SAATH, R.; SILVA TAVEIRA, J. H.; TERENCIANO, R. M.; THIAGO EVARISTO, T.; DEL ROSSO, B. C. Desempenho fisiológico e qualidade físicoquímica de grãos de soja secados sob diferentes temperaturas. Colloquium Agrariae, v.13, n.2, p.19-33,

2017.

https://doi.org/10.5747/ca.2017.v13.n2.a157

SALES, L. Ação de produtos stoller sobre a qualidade de grãos de soja. 2017. Monografia (Graduação em Agronomia) - Universidade Federal de Mato Grosso, Campus de Sinop, 2017. 
SOUZA, S. R. Beneficiamento e análise de qualidade de grãos de milho e soja na fazenda Campo Bom. Monografia (Graduação) Universidade Federal de Santa Catarina, Centro de Ciências Agrárias, 2012.

TEIXEIRA, G. V. Avaliação das perdas qualitativas no armazenamento da soja. Dissertação (Mestrado), Campinas, 2001.

TSUKAHARA, R. Y.; FONSECA, I. C. B.; SILVA, M. A. A.; KOCHINSKI, E.G.; PRESTES NETO, J. E.; SUYAMA, J. T. Produtividade de soja em consequência do atraso da colheita e de condições ambientais. Pesquisa Agropecuária Brasileira, v.51, n.8, p.905-915, 2016. https://doi.org/10.1590/S0100-

$\underline{204 \times 2016000800002}$

VINHOTE, J. A.; CORADINE, G.; SILVA, E. B. R.; SILVA, W. C.; SOARES, G. S. Aspectos relacionados à produção de soja no Brasil - uma revisão da literatura. 2021. Cap.9. https://doi.org/10.36599/editpa-2021 caiis-008

XAVIER, T. S.; DARONCH, D. J.; PELUZIO, J. M.; AFFÉRRI, F. S.; CARVALHO, E. V.; SANTOS, W. F. Época de colheita na qualidade de grãos de genótipos de soja. Comunicata Scientiae, v.6, p.241-245, 2015. 